UDC 811.111

DOI https://doi.org/10.26661/2414-1135-2020-80-1-18

\title{
PHYTOMIPHIC METAPHORS IN THE ENGLISH PROFESSIONAL LANGUAGE OF GOELOGY
}

\author{
Halai T. M. \\ Candidate of Philological Sciences, \\ Lecturer at the Department of the English Language \\ Ivano-Frankivsk National Technical University of Oil and Gas \\ Karpatska str., 15, Ivano-Frankivsk, Ukraine \\ orcid.org/0000-0003-3370-0727 \\ galajtania@gmail.com
}

Key words: metaphorical terms, geology, metaphorical model, frame, slot, plant.
The present paper sets out to examine the natural metaphoric model in the modern English terminology of geology. The investigation relies on the cognitive theory of metaphor and applies the method of metaphoric modeling by A. P. Chudinov. The results have revealed that the sphere-source "Plants" is an integral sphere-source for the formation of metaphorical terms in the English terminology of geology.

According to the cognitive linguistics, the metaphorical process involves the interaction of two spheres: the cognitive sphere-source and the sphere-target. The relationship between these spheres is schematically represented in the form of a metaphorical model with a special frame-slot structure.

Metaphorical terms of the model "GEOLOGICAL OBJECTS AND PROCESSES - THE KINGDOM OF PLANTS" verbalize information about geological objects and processes using the names of the plant world. It is noted that the analyzed metaphorical model is explained in metaphors belonging to 3 frames and 5 slots.

Within the frame "Composition of the plant world" $(61.6 \%$ of the terms of this metaphorical model) geological objects, namely atmospheric processes, geological formations, rock discharge systems, geological instruments and tools, are described through the prizm of terms denoting the genus and species of plants. It should be noted that the basis of the frame "Components (morphology) of the plant" (34.6\% of the terms of this metaphorical model) is formed by words included in the slots "Root", "Leaf" and "Seed". These words become the basis of metaphorical transference and are explicated in the English terms to denote geological bodies and formations, crystals of minerals and rocks.

The metaphors of the frame "Life cycle of plant development" $(3.8 \%$ of the terms of this metaphorical model) structure the knowledge about geological formations in terms of different cycles of plant development.

It is determined that the metaphorical transfer within the model "GEOLOGICAL OBJECTS AND PROCESSES - THE KINGDOM OF PLANTS” is based primarily on the associative features of appearance, shape and color. 


\title{
ФІТОМОРФНІ МЕТАФОРИ В АНГЛІЙСЬКІЙ ФАХОВІЙ МОВІ ГЕОЛОГІЇ
}

\author{
Галай Т. М. \\ кандидат філологічних наук, \\ викладач кафедри англійської мови \\ Івано-Франківський національний технічний університет нафти і газу \\ вул. Карпатська, 15, Івано-Франківськ, Україна \\ orcid.org/0000-0003-3370-0727 \\ galajtania@gmail.com
}

\begin{abstract}
Ключові слова: метафоричні терміни, геологія,

метафорична модель, фрейм, слот, рослина.
\end{abstract}

\begin{abstract}
Статтю присвячено дослідженню природоморфної метафоричної моделі в англійській геологічній термінології з позиції когнітивної лінгвістики за методикою А.П. Чудінова. У ході дослідження визначено, що метафорична модель являє собою бінарні зв'язки між визначеною сфероюджерелом і певною сферою-ціллю.

Аналіз лексикографічних джерел доводить, що невід' ємною сферою-джерелом утворення метафоричних термінів $\epsilon$ сфера-джерело «Світ рослин». Зазначається, що на тлі когнітивного напряму процес метафоризації передбачає взаємодію двох сфер: когнітивної сфери-джерела та сфери-цілі. Схематично зв'язок між цими сферами представлено у вигляді метафоричної моделі, яка має особливу фреймо-слотову структуру. Метафоричні терміни моделі «ГЕОЛОГІЧНІ ОБ'ЄКТИ ТА ПРОЦЕСИ ЦЕ ЦАРСТВО РОСЛИН» вербалізують інформацію про геологічні об'єкти та процеси через номінації найменувань об'єктів світу рослин. Встановлено, що аналізована метафорична модель експлікується в метафорах, які належать до 3-х фреймів та 5-ти слотів.

У межах фрейму «Склад світу рослин» (61,6\% від числа термінів цієї метафоричної моделі) геологічні терміни на позначення атмосферних процесів, геологічних утворень, систем скидів гірських порід, геологічних приладів та інструментів описуються за допомогою термінів на позначення роду рослин (genus of plants) та виду рослин (species of plants). Зазначається, що основу фрейму «Складові частини (морфологія) рослини» (34,6\% від числа термінів цієї метафоричної моделі) утворюють слова, що входять до слотів «Корінь», «Листок» та «Насіння». Вони стають базою метафоричного перенесення та експлікуються в англійських термінах на позначення геологічних тіл і утворень, кристалів мінералів та гірських порід. Розглянуто метафори фрейму «Життєвий цикл розвитку рослин» (3,8\% від числа термінів цієї метафоричної моделі), які структурують знання про геологічні утворення в термінах на позначення різних циклів розвитку рослин. Визначено, що метафоричне перенесення в рамках цієї моделі базується насамперед на асоціативних ознаках зовнішнього вигляду, форми та кольору.
\end{abstract}

The dynamic development of geological science in the 21 st century is reflected, above all, in the geological technical language, which ensures effective, high-quality and accurate communication between specialists in the field. The English technical language of geology is currently in an active phase of development and is characterized by a large corpus of data containing more than 1175 metaphorical terms that require special investigation.

Analysis of recent research results and publications. We must note that the context of the English technical language of geology hasn't been studied thoroughly. E. V. Bessonova has analyzed the semantic and structural features of the terminology of general geology [1]. E.P. Stemkovskaia has investigated the semantic and word-forming structures of Russian terminology of seismic exploration [2]. O.I. Strizhevskaia has researched the structural and semantic peculiarities of mineral names [3]. R.M. Sultanova has conducted the comparative analysis of geological terminology in Russian and Tajik languages [4]. T.A. Volkova's research includes the analysis of the peculiarities of the translation of English and Russian geological abbreviations [5]. I.N. Zhuravleva has studied the methods of nomination, lexical and semantic processes in modern French geological terminology [6]. The English 
technical language of geology, especially the layer of its metaphorical terms, has not yet been the subject of research.

The topic of the functioning of metaphors has attracted the attention of both foreign and Ukrainian linguists (N.D. Arutiunova, A.M. Baranov, A.P. Chudinov, M. Johnson, G. Lakoff, V.A. Maslova, D.M. Shmelev, V.M. Telia, M.M. Volodina). Extensive experience has been accumulated in the study of metaphorical processes in the terminology of professional languages from a traditional and cognitive point of view. Particularly noteworthy are the works of O.P. Vynnyk (economic terminology), T.S. Vershinina, H.P. Datsyshyn (political terminology), S.G. Dudetskaia (medical terminology), O.O. Efremova (oil and gas terminology), Y.I. Hrybinyk (geodetic terminology) and others. Noteworthy, however, is the insufficient study of metaphorical terms in the cognitive aspect in the English technical language of geology.

The relevance of our research is predetermined by the linguists' interest in studying a metaphor as a universal mechanism that reveals the cognitive properties of human thought and covers various fields of knowledge, including professional languages, and in our case, geological terminology.

It is the first experience in describing the phytomorphic metaphor, which is the key to interpreting geological objects and processes.

The aim of this research is to explore phytomorphic metaphors that conceptualize geological objects, processes and objects. We have chosen phytomorphic metaphorical terms in the English technical language of geology as the object of our research. The subject of our research is the metaphorical model "GEOLOGICAL OBJECTS AND PROCESSES THE KINGDOM OF PLANTS".

The following objectives were outlined: the systematization and description of phytomorphic metaphorical terminological units based on the model "GEOLOGICAL OBJECTS AND PROCESSES THE KINGDOM OF PLANTS", as well as their analysis with regard to their frame-slot structure.

Material and methods of research. The researched material includes a corpus of 1175 metaphorical terms selected from modern English explanatory and encyclopedic dictionaries of geology, published between the year 2001 and 2013: "Dictionary of Applied Geology English - French - German Spanish" B. Merkel (2001), "Penguin Dictionary of geology" Philip Kearey (Penguin reference, 2001), Dictionary of Geology and Mineralogy (McGrawHill Professional, 2003), Dictionary of Earth Science (McGraw-Hill Companies, 2003), "Illustrated dictionary of Geology" Cindy Jones (2005), "Glossary of Geology" K. E. Klaus (2005), “A Dictionary of Earth Sciences" by M. Allaby (Oxford University Press, 2008), "General Dictionary of Geology" by Alva Kurniawan (2009), "Dictionary of Geology and Earth Sciences" (Oxford University Press Print, 2013), "Dictionary of Geology and Mineralogy" William Humble (Forgotten Books, 2013). The number of pages amounted to 4268 pages in English.

The methodology of our research combines the tools of the cognitive theory of metaphor [7] and metaphorical modeling [8] to build the lingvo-cognitive metaphorical model "GEOLOGICAL OBJECTS AND PROCESSES - THE KINGDOM OF PLANTS".

Presenting main material. Nature, natural phenomena, fauna and flora are the considerable source of metaphorization in the English technical language of geology.

One of the most popular models of metaphorical nomination is the phytomorphic metaphor, based on phytomorphisms, namely the names of plants $[9$, p. 1806]. The metaphoric terms of the model "GEOLOGICAL OBJECTS AND PROCESSES - THE KINGDOM OF PLANTS" are based on the model of transferring the name of a plant or its individual parts to geological objects.

It is important to mention that in our study, we use the definition of A.P. Chudinov, who believes that communication scheme between conceptual domains, existing in the minds of native speakers, can be represented by the formula: " $\mathrm{X}$ - is $\mathrm{Y}$ " [10], where $\mathrm{X}$ is the sphere-target and $\mathrm{Y}$ is the sphere-source. The name of the metaphorical model is the genus-type of concept that combines the elements of its taxa" [11, p. 31].

The metaphorical model is structured by means of frames and slots. The attractiveness of using the frame analysis to the study of linguistic phenomena is that the frame allows you to clearly structure the idea of an object. Frame is a unit of knowledge, whose structure is built around a concept and contains data related to this concept. It is a kind of knowledge framework for depicting a stereotypical situation [10, p. 132]. T.S. Vershynina accentuates that a slot is one of the parts of the frame [12, p. 21]. Slots are elements of situations, a certain type of information, that is relevant to a fragment of the described reality [13, p. 106].

It is essential to mention that the consideration of the analyzed metaphorical model in the English technical language of geology is based on the method of analysis and classification of metaphorical models developed by A.P. Chudinov [14], who believes that in order to describe the metaphorical model, one must characterize the original conceptual sphere (the source sphere), a new conceptual sphere (the sphere-target) and the component connecting the primary and secondary values covered by this model. Characterizing this component, we can find out what provides a basis for the metaphorical use of relevant concepts, why the conceptual structure of the spheresource is suitable to denote elements of a completely 
different sphere; typical of this model frame-slot structure [14, p. 29-30].

In the English technical language of geology the metaphorical model "GEOLOGICAL OBJECTS AND PROCESSES - THE KINGDOM OF PLANTS" represents $2.2 \%$ of the total sample of metaphorical terms. The phytomorphic metaphorical model is realized with the help of conceptual metaphors of the frames "Composition of the plant world" (61.6\%), "Components of plants (plant morphology)" (34.6\%), "Life cycle of plant development" (3.8\%).

According to the study, the frame "Composition of the plant world" is the most productive within the phytomorphic metaphor. Geological processes, phenomena and objects are named with the title names of the genus and species of plants. These metaphoric terms are included in the following slots: "The genus of plants" (salt flower, lava tree), "Species of plants" (rose diagram).

Metaphorical terms within the slot "Genus of plants" are used to nominate geological objects according to the associative external resemblance to plants and serve as a source for metaphorical rethinking of atmospheric processes and their consequences. For example, the word "flower", which means "a coloured or white part that a plant or tree produces before fruit or seeds", has acquired a special meaning "ice formations" in the English technical of geology due to metaphorical transfer. Namely the term "ice flower" denotes ice crystals on the surface of sea ice as a result of the rapid freezing of sea water ("formations of ice crystals formed on salt nuclei on the surface of sea ice as a result of the rapid freezing of sea water").

The word "flower" meaning "the seed-bearing part of a plant, consisting of reproductive organs (stamens and carpels) that are typically surrounded by a brightly coloured corolla (petals) and a green calyx (sepals)" is fixed in geological terminology in a metaphorical terminological phrase ("flower structure") and means a system of gaps in large displacement zones that have a vertical shape resembling a flower ("an array of upward-diverging fault splays within a strike-slip zone"). Understanding and perceiving the geological faults is determined by their description through the prism of the appearance of a flower.

The results of the volcanic eruption are illustrated by the terms "lava tree", "lava tree mold", "lava tree cast". According to the Oxford Dictionary, the word "tree" means "a woody perennial plant, typically having a single stem or trunk growing to a considerable height and bearing lateral branches at some distance from the ground". In geological terminology, the noun "tree" is the key word in the above mentioned metaphorical terms (lava tree, lava tree mold, lava tree cast) and denotes a mold of a lava tree, which protrudes above the surface of the Earth ("a half cylindrical projection above the surface of a lava flow, formed when fluid lava flows against the upstream side of a tree").

Quite common is the nomination of geological objects according to their similarity to the plant species (slot "Species of plants"). For example, the deep structures of the upper parts of the Earth's crust are reflected with the help of the metaphorical term "tulip structures" meaning concave upwards fractures in transtensional environment that resemble a tulip flower. The geological term "palm tree structure" nominates the system of dumps or thrusts with the raising of the central blocks. Metaphorical transfer is based on the similarity of form.

The sphere-target of the metaphorical nomination of this slot often includes terms to denote the rocks such as "chestnut coal" meaning anthracite coal small enough to pass through a round flower structure mesh of 15/8 inches ( 3.1 centimeters) but too large to pass through a round mesh of 113/16 inches. Metaphors are based on colour similarity.

In the English language of geology the associative connections of the rose (a flower which often has a pleasant smell, and is usually red, pink, white, or yellow, or the bush that this flower grows on) with diagrams used in geological practice can be traced considering the geological term "rose diagram", which means "a circular graph indicating values in several classes of vector properties of rocks such as cross-bedding direction". Another example is the metaphorical term "wind rose" to denote the diagram, that characterizes the wind regime in a certain place according to long-term observations and looks like a polygon in which the lengths of rays diverging from the center of the diagram in different directions are proportional to the wind repeats of these directions.

If we metaphorically rethink the colour of a chestnut in the English technical language of geology we'll find the term "chestnut soil", which means "one of the major groups of zonal soils, developed typically in temperate to cool, subhumid to semiarid climate", soil with a dark brown surface horizon, under which there are lighter horizons and lime clusters.

On the basis of the data presented it is possible to claim that metaphorical images relating to the shape and colour of a particular plant form an idea of the shape, colour and structure of a geological object and phenomenon.

Very productive and structured is the frame "Components (morphology) of the plant". This frame uses slots such as "Root", "Seed" and "Leaf".

The denotative scope of the metaphorical geological terms of the slot «Root" covers a wide range of geological objects. For example, geological terms to denote: a layer of clay or other fine-grained detrital material underlying a coal bed or comprising the floor of a coal seam ("root clay"), geological formations, namely the term "rootless vent", which refers to a 
source of lava that is not directly related to a volcano crater or igneous source. It may be part of a lava flow that solidified outside a volcanic crater. Geological terms are metaphorized in the analyzed technical language on the basis of associations according to the localization principle.

Seed nominations often become donors for the creation of geological terms to denote minerals. For example, the geological term "seed crystal" means " $a$ small, suitably priented piece of crystal used in crystal seeding".

Slot "Leaf". The names of leaves are often used to denote the structure of rocks (leaf, leaf clay, leaf old, leaf peat). The motivating feature in this case is external similarity. Thus, the English explanatory dictionaries of geological terms record the metaphorical term "leaf peat" that means layered peat consisting of thin layers of plant residues that alternate with layers of sapropel.

The frame "Life cycle of plant development" conveys the dynamics of geological processes. Due to the insufficient variety of metaphorical units it did not confirm its performance. Therefore, we decided that it would be impractical to single out slots in this frame. In this frame, the geological term "blossom" is used metaphorically to denote the oxidized or decomposed outcrop of a vein or coal bed. The unproductive use of English geological metaphors in this frame is explained by the fact that the main representation of images of geological objects and processes lies in other conceptual areas.

Conclusions and perspectives. The metaphorical terms belonging to the analyzed metaphorical models are realized by means of conceptual metaphors from three frames and develop figurative values based on the associative similarity in appearance, shape, color and nature of the location of the components of plant parts and offers a description of geological objects and processes regarding the genus and species of plants, their morphology and development. Words from the sphere-source "Plants" become the basis for metaphorical understanding of geological terms from the sphere-target, which includes nominations of geological formations, tools, geological formations, rocks, relief types, minerals and mineral formations, devices for geological research.

Quantitative analysis of geological metaphorical terms with a phytomorphic component revealed that the most productive sources of metaphorization in the English technical language of geology within this model are the names of the plant genus $-30.8 \%$, the names of the plant species $-30.8 \%$, root $-15.4 \%$; leaf $-15.4 \%$. Less represented are the nominations of seed $-3.8 \%$ and lifecycle of plants $-3.8 \%$.

We see the prospects for future research in the study of geological terminological metaphors from the social and natural sphere-sources.

\section{BIBLIOGRAPHY}

1. Бессонова Е.В. Семантика и структура русской общегеологической терминологии : дисс. ... канд. филол. наук : 10.02.01. Москва, 1985. $206 \mathrm{c}$.

2. Стемковская Е.П. Семантическая и словообразовательная структура русской терминологической лексики: Терминология сейсмической разведки : автореф. дисс. ... канд. филол. наук : 10.02.01. Москва, 1971. $21 \mathrm{c}$.

3. Стрижевская О.И. Структура и семантика названий минералов : автореф. дис. ... канд. филол. наук : 10.02.01. Москва, 1975. 25 с.

4. Султанова Р.М. Сопоставительный анализ геологической терминологии в русском и таджикском языках : автореф. дисс. ... канд. филол. наук : 10.02.20. Душанбе, 2013. 27 с.

5. Волкова Т.А. Перевод английских и русских геологических аббревиатур. Вестник Пермского национального исследовательского политехнического университета. Проблемы языкознания и педагогики. Пермь, 2015. № 3 (13). C. 44-53. URL: http://cyberleninka. $\mathrm{ru} /$ article/n/perevod-angliyskihi-russkihgeologicheskih-abbreviatur

6. Журавлева И.А. Способы номинации и лексико-семантические процессы в современной французской геологической терминологии : дис. ... канд. филол. наук : 10.02 .05 ; КГУ им. Т Г. Шевченка. Киев, 1991. 240 с.

7. Лакофф Дж. Метафоры, которыми мы живем : монография / под ред. и с предисл. А.Н. Баранова. Москва : Едиториал УРСС, 2004. 252 с.

8. Чудинов А.П. Очерки по современной политической метафорологии : монография. Екатеринбург, 2013. 176 с.

9. Баймурзина А.М. Биоморфная метафорическая модель как средство фразеологизации понятия «богатство» в современном немецком языке. Вестник Башкирского университета. Уфа, 2012. Т. 17. № 4. С. 1803-1807.

10. Чудинов А.П. Политическая лингвистика : учеб. пособие. Москва : Изд. «Флинта», «Наука». 2006. 248 c.

11. Мишланова С.Л. Когнитивный аспект метафоризации в медицинском дискурсе. Научно-техническая терминология. Моска, 2003. Вып. 1. С. 30-36.

12. Вершинина T.С. Метафорические модели с исходной биологической сферой в современном политическом дискурсе : дисс. ... канд. филол. наук : 10.02 .01 ; Уральский государственный педагогический университет. Екатеринбург, 2002. 207 с.

13. Андрейченко O.I. Артефактна метафора в сучасному політичному дискурсі: когнітивний аспект. Лінгвістичні студії. Вінниця, 
2011. Вип. 23. С. 106-110. URL: http://nbuv. gov.ua/UJRN/lingst_2011_23_25 (дата звернення: 28.08.2019).

14. Чудинов А.П. Финансовая метафора в современной политической речи. Известия Уральск. гос. пед. ун-та. Лингвистика. Екатеринбург, 2001. Вып. 7. URL: http://www. philology.ru/linguistics2/chudinov-01.htm

\section{REFERENCES}

1. Bessonova E. V. (1985) Semantika i struktura Ruskoi obshchegeologicheskoi terminologii [Semantics and structure of Russian general geological terminology] ( $\mathrm{PhD}$ Thesis), Moscow.

2. Stemkovskaya E. P. Semanticheskaya I slovoobrazovatelnaya stuctura Ruskoi terminologicheskoi leksiki : terminologiya seismicheskoi razvedki [Semantic and word-formation structure of the Russian terminology vocabulary : Terminology of seismic exploration] (Extended abstract of $\mathrm{PhD}$ thesis), Moscow.

3. Strizhevskaya O. I. (1975) Struktura I semantika nazvanii mineralov [Structure and semantics of mineral names] (Extended abstract of $\mathrm{PhD}$ thesis), Moscow.

4. Sultanova R. M. (2013) Sopostavitelnyi analiz geologicheskoi terminologii v ruskom i tadzhykskom yazykakh [Comparative analysis of geological terminology in Russian and Tajik languages] (Extended abstract of $\mathrm{PhD}$ thesis), Dushanbe.

5. Volkova T. A. (2015) Perevod angliiskikh I ruskikh geologicheskikh abreviatur [Translation of English and Russian geological abbreviations] Vestnik Permian National Research Polytechnic University. Problems of Linguistics and Pedagogy, no. 3 (13), pp. 44-53. - Access mode : http://cyberleninka.ru/article/n/perevodangliyskih-i-russkih-geologicheskih-abbreviatur).

6. Zhuravleva I. A. (1991) Sposoby nominatsii $i$ leksiko-semanticheskie protsesy $v$ sovremennoi frantsuzkoi geologicheskoi terminologii [Methods of nomination and lexical-semantic pro- cesses in modern French geological terminology] (PhD Thesis), Kiev: Kiev National University of T. H. Shevtchenko.

7. Lakoff G. (2004) Metafory, kotorymi my zhyvem [Metaphors we live by]. Moscow: Editorial URSS.

8. Chudinov A. P. (2013) Ocherki po sovremennoi politicheskoi metaforologii [The Essays on Modern Political Metaphorology]. Yekaterinburg.

9. Baimurzina A. M. (2012) Biomorfnaya metaforicheskaya model kak sredstvo frazeologezatsyi ponyatiya "Bogatstvo" v sovremennom nemetskom yazyke [Biomorphic metaphoric model as a means of a phraseology of a notion "wealth" in the modern German language]. Bakshyr University Vestnik, vol. 17, no. 4, pp. 1803-1807.

10. Chudinov A. P. (2006) Politicheskaya lingvistika [Political Linguistics]. Moscow: Flint.

11. Mishlanova S. L. (2003) Kognitivnyi aspect metaforizatsii $\mathrm{v}$ meditsinskom diskurse [The Cognitive Aspect of Metaphorization in Medical Discourse]. Scientific and Technical Terminology, no. 1 , pp.30-36.

12. Vershinina T. S. (2002) Metaforicheskie modeli $s$ iskhodnoi biologicheskoi sferoi $v$ sovremennom politicheskom diskurse [Metaphorical Models with the Original Biological Sphere in Contemporary Political Discourse], (PhD Thesis), Yekaterinburg: Ural State Pedagogical University.

13. Andreichenko O. (2011) Artefaktna metafora v suchasnomu politychnomy dyskursi: kignityvnyi aspect [An artifact metaphor in contemporary political discourse: cognitive aspect]. Linguistic studios, no. 23, pp. 106-110.

14. Chudinov A. P. (2001) Finansovaya metafora v sovremennoi politicheskoi rechi [Financial metaphor in the modern political speech]. Izvestiye Uralskogo gosudarstvenogo pedagogitcheskogo universiteta. Lingvistika [Proceedings of the Uralsk National pedagogical university. Linguistics], vol. 7. URL: http://www.philology.ru/linguistics2/chudinov-01.htm. 